\title{
Paleo-environmental evolution as revealed by analysis of organic carbon and nitrogen: A case of coastal Taipei Basin in Northern Taiwan
}

\author{
Huei-Wei Ku, ${ }^{1}$ Yue-Gau Chen, ${ }^{1 *}$ Po-Shun Chan, ${ }^{2}$ Huan-ChI LiU ${ }^{3}$ and ChaO-Chung Lin ${ }^{3}$ \\ ${ }^{1}$ Department of Geosciences, National Taiwan University, Taipei, Taiwan, R.O.C. \\ ${ }^{2}$ School of Civil Engineering, Purdue University, West Lafayette, IN 47906, U.S.A. \\ ${ }^{3}$ Central Geological Survey, Taiwan, R.O.C.
}

(Received February 22, 2006; Accepted January 4, 2007)

\begin{abstract}
In an attempt to discriminate different sources of organic matter and reconstruct the paleo-environment of the Taipei Basin, northern Taiwan over the past 250,000 years, organic carbon and nitrogen content ( $\mathrm{C} / \mathrm{N}$ ratios) and isotope composition $\left(\delta^{13} \mathrm{C}\right.$ and $\left.\delta^{15} \mathrm{~N}\right)$ are measured for sediment samples collected from core $\mathrm{Wu}$-ku drilled at the depocenter in western Taipei Basin. The high $\delta^{13} \mathrm{C}$ values (up to $-17.0 \%$ ) and high $\mathrm{C} / \mathrm{N}$ ratio (up to 14.9 and 13.0, respectively) indicate that this area underwent a period of relative aridity during MIS 2 and mid MIS 6 . Another two periods of high and variable $\delta^{15} \mathrm{~N}$ values (up to 15.5 and 13.5\%o, respectively) in MIS 1 and MIS 7 represent different nutrient condition in the basin. In MIS 1 , high $\delta^{15} \mathrm{~N}$ variability along with increasing TOC may reflect an unstable trend of aquatic productivity related to the dynamic mixing ratios of seawater and fresh water. The high $\delta^{15} \mathrm{~N}$ values observed in the sediments of MIS 7 could be explained by the employment of a ${ }^{15} \mathrm{~N}$-enriched nitrate from denitrification as the main source of nitrogen for primary producers.
\end{abstract}

Keywords: organic matter, $\delta^{13} \mathrm{C}, \delta^{15} \mathrm{~N}, \mathrm{C} / \mathrm{N}$ ratios, Taipei Basin

\section{INTRODUCTION}

Taipei Basin, located in northern Taiwan (Fig. 1), is triangular in shape and was tectonically created by normal faulting along its western margin (Wang-Lee et al., 1978; Teng et al., 2000). Five radiocarbon ages were obtained from the woody tissues collected from the Sungshan Formation and two thermoluminescence (TL) ages were used as age controls (Liu et al., 1988; Wei et al., 1998). The fault-based subsidence has resulted in the accumulation of sediments in the basin since 0.4 Ma. Throughout its depositional history, the Taipei Basin has been characterized by alluvial fans, fluvial plains, and estuaries in response to the fluctuating sea levels of the Pleistocene. At $200 \mathrm{ka}$, the Basin outlet was dammed by the latest phase of volcanic activity associated with the Tatun volcanoes in the north, turning it into a deep freshwater lake. At $30 \mathrm{ka}$, the Tahan River, one of three major tributaries of Tanshui River, was captured into the Basin, pouring in a great amount of coarse sediment to build up a basin-wide alluvial fan. In the early Holocene, the Basin was again inundated by seawater and became a brackish lake. The lake was subsequently filled up to its present

\footnotetext{
*Corresponding author (e-mail: ygchen@ntu.edu.tw)

Copyright (c) 2007 by The Geochemical Society of Japan.
}

levels (Teng et al., 2001). Based on this general sedimentary history, the possible sources of the organic matter in the sediments of the Taipei Basin are 1) terrestrial biomass, soil and lithic fragments from the higher land area, and 2) the organic matter derived from in-situ plankton and benthic sources. This study employs $\delta^{13} \mathrm{C}$ and $\delta^{15} \mathrm{~N}$ values, bulk abundances of carbon (TOC) and nitrogen (TON) and atomic $\mathrm{C} / \mathrm{N}$ ratios to diagnose detailed paleoenvironmental information derived from the deepest core drilled in the Basin.

Bulk abundance of carbon and nitrogen (TOC and TON) has been used as first-order indicators of organic matter flux and diagenesis (Meyers, 1997). Although a large number of individual factors influence the various TOC and TON values of sediments, three master variables always apply: the input flux of organic matter, diagenesis, and sedimentation rate (e.g., Tyson, 1995). If the sedimentation rate is relatively steady in certain duration, high TOC and TON indicate increases of the input flux of organic matter. Furthermore, an X-Y plot of TON vs. TOC can be used to examine the diagenetic degradation of carbon coupled nitrogen (Schubert and Calvert, 2001) to examine the reliability of the study material. Atomic $\mathrm{C} / \mathrm{N}$ ratios and isotopic analysis of bulk sediment have been widely used to discriminate various organic sources in order to reconstruct depositional environments, or vegetation changes (Tenzer et al., 1999; Schubert and 


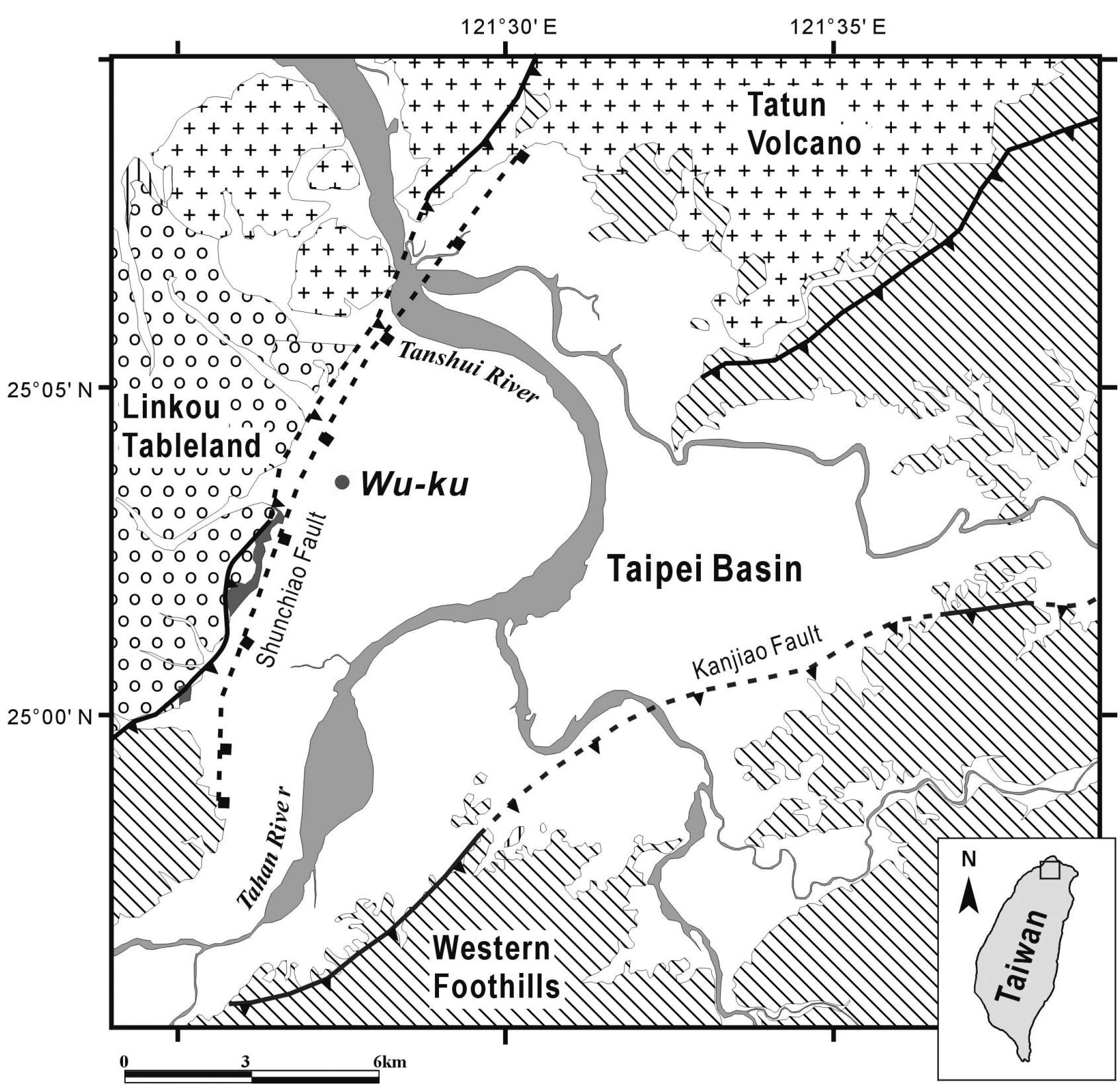

Fig. 1. Map showing the location of core Wu-ku in northern Taiwan.

Calvert, 2001). The $\mathrm{C} / \mathrm{N}$ ratio is a good indicator of the protein content in sediments. Plants, in general, have higher $\mathrm{C} / \mathrm{N}$ ratios than animals due to their low protein and high cellulose content. The $\mathrm{C} / \mathrm{N}$ ratios of organic matter derived from lacustrine primary production have an average value between 5 and 6 , whereas that of higher terrestrial plants are usually higher than 20 (Meyers, 1997; Muller and Voss, 1999). Bordovskiy (1965) concluded that a $\mathrm{C} / \mathrm{N}$ ratio of $<8$ indicates an origin of aquatic organic source, while a ratio of $>12$ represents the dominance of a terrestrial organic source (Prahl et al., 1980).
Stable isotope ratios of organic carbon and nitrogen are also useful tracers for delineating and identifying formation processes and sources of organic matters (Thornton and McManus, 1994; Middelburg and Nieuwenhuize, 1998). The $\delta^{13} \mathrm{C}$ values of organic carbon have long been recognized as providing the syndepositional signals for source identification (Arthur et al., 1988; Talbot and Johannessen, 1992; Meyers and Horie, 1993; Street-Perrott et al., 1997; Muller and Voss, 1999) and are relatively conservative in comparison with nitrogen isotope values or $\mathrm{C} / \mathrm{N}$ ratios (Thornton and 
McManus, 1994). Isotopic ratios are affected by a number of factors (Stuiver, 1975; Hakansson, 1985) such as $\left[\mathrm{CO}_{2(\mathrm{aq})}\right]$, temperature, and climate, which leave their fingerprints in the carbon isotope ratios. Besides the primary producer (i.e., algae), particulate organic matter buried in sediments is often a mixture of material derived from different sources (e.g., aquatic biomass, and terrestrial plants: Meyers, 1994). Each of these sources is characterized by different isotopic values (Deines, 1980; O'Leary, 1988). Primary producers and macrophytes have wide-ranged $\delta^{13} \mathrm{C}$ values from -17 to $-27 \%$. On the other hand, the source of terrestrial plants are dominated by two distinct vegetation groups, C3 and C4 plants employing different photosynthesic pathways that produce different $\delta^{13} \mathrm{C}$ values: C3: $-27.1 \pm 2.0 \%$; C4: $-13.1 \pm 1.2 \%$ (Deines, 1980; O'Leary, 1988). Generally, in the semitropical environment of Taiwan, C3 plant grows under humid conditions, while $\mathrm{C} 4$ plant under relatively arid conditions. Therefore, $\delta^{13} \mathrm{C}$ values can be used not only as an indicator of the change of terrestrial plant populations but also a good proxy of the history of climate change.

The natural ratio of ${ }^{15} \mathrm{~N}$ and ${ }^{14} \mathrm{~N}$ provides a way to trace nitrogen sources among nutrient pools, which has been widely applied in environmental studies (e.g., Macko and Ostrom, 1994; Michener and Schell, 1994; Meyers, 1997). Nitrogen availability in lacustrine systems in fact constrains primary production. Nitrogen isotope ratios $\left(\delta^{15} \mathrm{~N}\right)$ range from $-3 \%$ for some plankton to more than $+18 \%$ for complex aquatic organisms (Wada et al., 1975; Minagawa and Wada, 1984). On the other hand, terrestrial plants have a $\delta^{15} \mathrm{~N}$ range of -5 to $+18 \%$ with an average of $+3 \%$ (e.g., Schoeninger and DeNiro, 1984). The sedimentary $\delta^{15} \mathrm{~N}$ values in lakes are subject to the kinetic isotope fractionation effects during the biogenic metabolism of dissolved and particulate nitrogen compounds (Owens, 1987). Major biogeochemical processes including ammonification, nitrification, denitrification, and nutrient assimilation tend to result in the product with $\delta^{15} \mathrm{~N}$ values lower than their substrates. Previous studies also suggest that the sedimentary $\delta^{15} \mathrm{~N}$ values can be used to infer the nature and fate of sinking organic matter, such as productivity in the past (Brandes and Devol, 1997; Voss and Struck, 1997).

Using a combination of stable carbon and nitrogen isotopes and the $\mathrm{C} / \mathrm{N}$ ratio of organic matter provides a means to discriminate the different sources of organic matter. Furthermore, it can also show the mixing trend between terrestrial and aquatic source of organic matter (Meyers, 1997; Ohkouchi et al., 1997; Muzuka and Hillaire-Marcel, 1999; Muller and Voss, 1999; Huon et al., 2002). The $\delta^{13} \mathrm{C}$ of $\mathrm{C} 3$ plants $(-26$ to $-28 \%$ ) and $\mathrm{C} 4$ plants $\left(-12\right.$ to $-14 \%$ ) ; the $\delta^{15} \mathrm{~N}$ of $3 \%$, and a $\mathrm{C} / \mathrm{N}$ ratio of $>12$ are used as the terrestrial end member. On the other hand, the $\delta^{13} \mathrm{C}$ of $-19 \%$ to $-28 \%$; the $\delta^{15} \mathrm{~N}$ of +2 to $+5 \%$ o and the $\mathrm{C} / \mathrm{N}$ ratio of $<8$ are applied as the aquatic end member.

The five radiocarbon and two TL ages are plotted next to the lithological profiles in Fig. 2. Based on the chronological results of the Linkou Tableland, Kuanyin Volcano and Tatun Volcanic Group (Fig. 1), the commencement of the Basin deposition has been suggested as younger than $0.4 \mathrm{Ma}$ (Wei et al., 1998). The sedimentation rate estimated using ${ }^{14} \mathrm{C}$ data are $0.72 \mathrm{~cm} / \mathrm{yr}$ in MIS 1. The first grey line in Fig. 2, representing the boundaries between MIS 1/2 (Martinson et al., 1987; Linsley and Dunbar, 1994), is drawn based on age results from the Taipei Basin. The upper and lower boundaries of MIS 5 are associated with a warm pollen zone (Liew et al., 1997). The Chingmei Formation and Wu-ku Formation therefore can be correlated to stage 2 and 6 , respectively.

Based on seismic data (Wang et al., 1994, 1995), the depocenter of the basin is located in the $\mathrm{Wu}-\mathrm{ku}$ area, where a borehole was sunk in order to secure a complete sedimentary profile of the Basin (Fig. 1). This study utilizes the sediments collected from $\mathrm{Wu}-\mathrm{ku}$ core, which preserves a continuous sedimentary record of $250 \mathrm{ka}$ for a drilling depth of $400 \mathrm{~m}$ (Fig. 2). Previous sedimentological and foraminiferal studies have documented that most of $\mathrm{Wu}$ $\mathrm{ku}$ sediments were accumulated under terrestrial freshwater conditions, except for the marine incursion in the early Holocene (Huang, 1995). The average annual runoff of Tanshui River is $7043.97 \times 10^{6} \mathrm{~m}^{3} / \mathrm{yr}$ and the average annual sediment discharge is $11.45 \times 10^{6} \mathrm{MT} / \mathrm{yr}$ implies that the terrestrial input from the river catchment dedicate an important part of the sediments to Taipei Basin (Water Resources Bureau, Ministry of Economic Affairs, 1995). Palynological studies suggest three warmcold climate cycles since the middle Pleistocene (Liew et al., 1997). The organic carbon isotope study of Wei et al. (1998), previously demostrated that the low sea-level period is associated with high $\delta^{13} \mathrm{C}$ values in the Taipei basin and the first-order paleoenvironment information recorded in the $\mathrm{Wu}-\mathrm{ku}$ core is in response to the global glacial-interglacial transition. However, Wei used a sample interval of $10 \mathrm{~m}$ and only $\delta^{13} \mathrm{C}$ values and was unable to probe the details and information derived from nitrogen context. This study presents longer and more dense analyses including both abundance and stable isotope values of carbon and nitrogen. More detailed information of paleoenvironment is expected.

\section{Materials AND Methods}

Fresh plant tissues and surface sediments were collected from the estuary of the Tamshui River (Fig. 1). Sediments from the $\mathrm{Wu}-\mathrm{ku}$ core were sampled in intervals of around $2 \mathrm{~m}$. Each subsample was dried at $60^{\circ} \mathrm{C}$ 

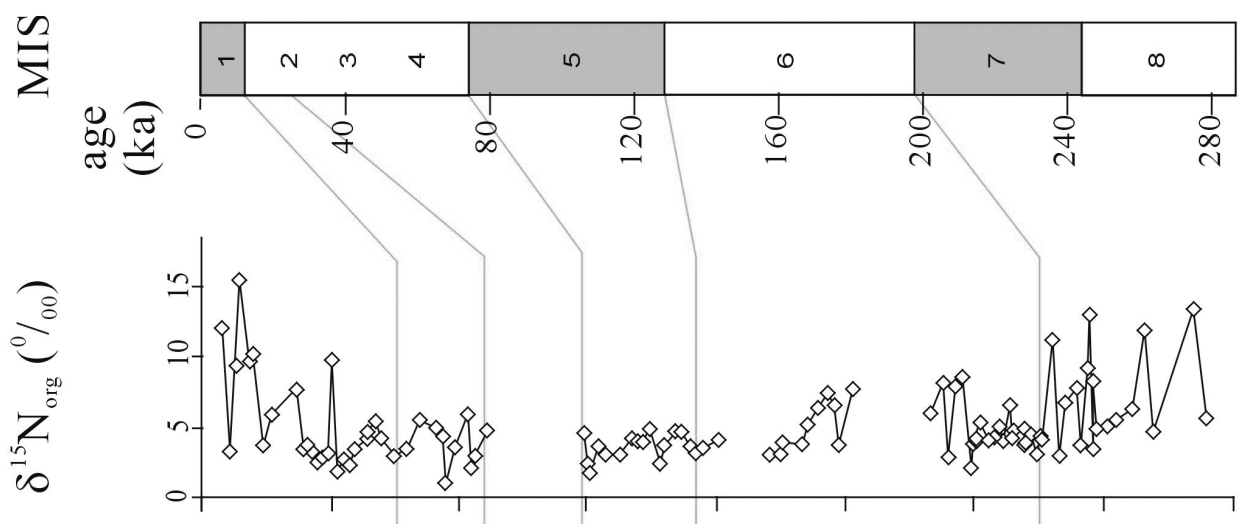

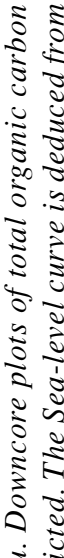

(8)

Z

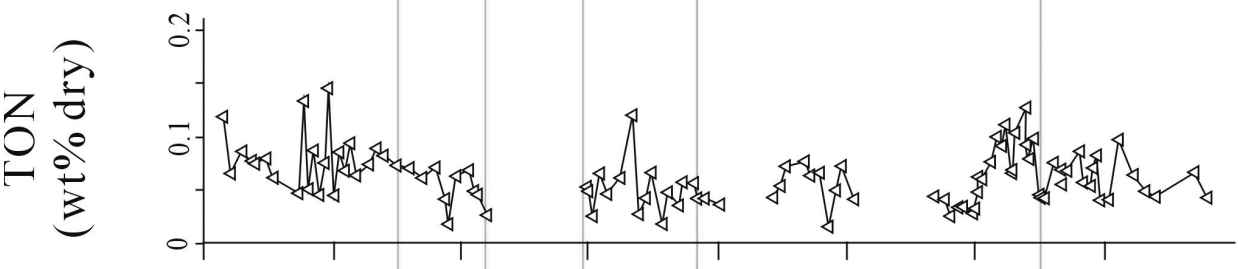
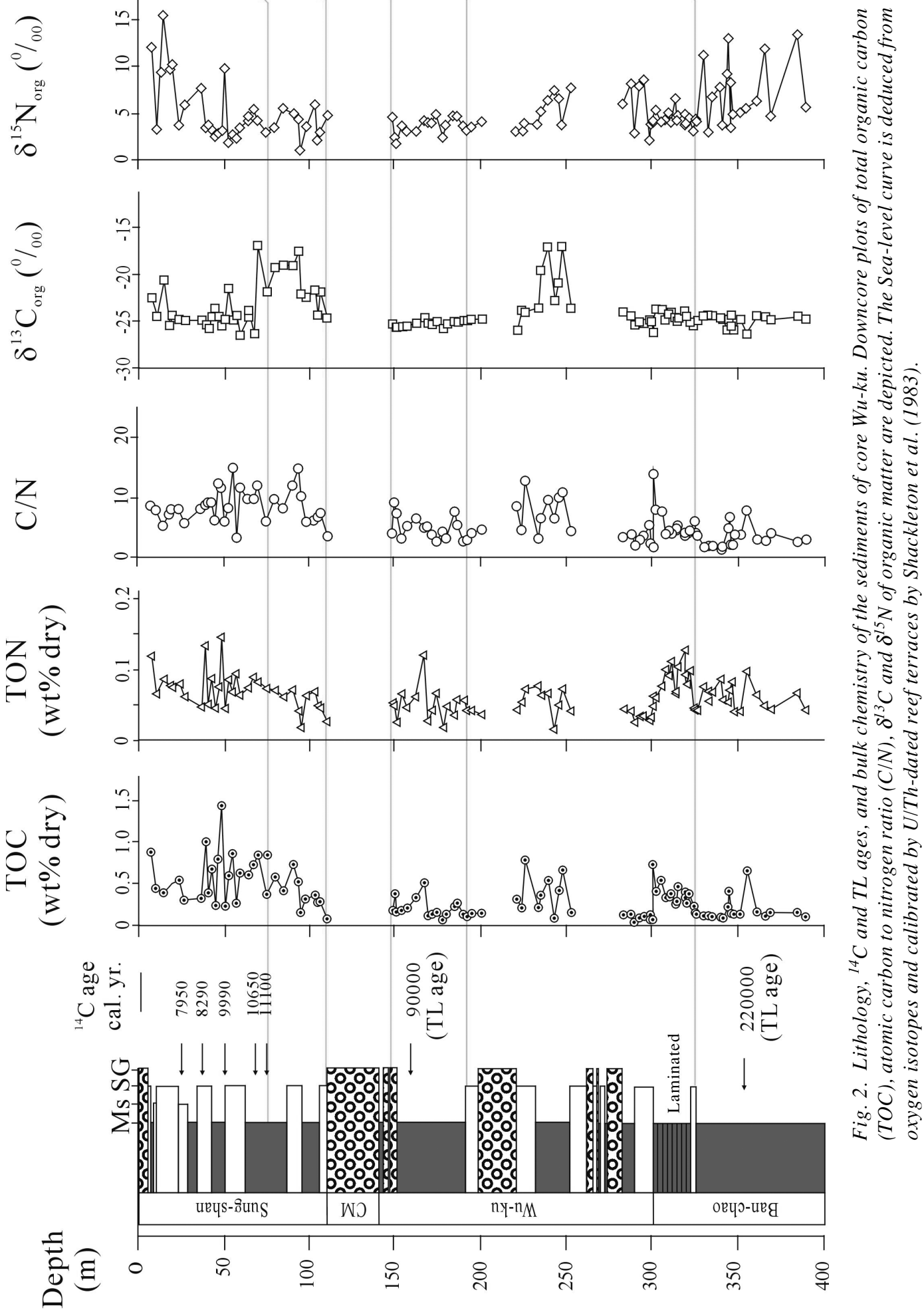
Table 1. Average values of $\mathrm{C} / \mathrm{N}$ ratio, carbon and nitrogen isotopic values of core $W u-k u$

\begin{tabular}{lrrrrrr}
\hline Stages & \multicolumn{1}{c}{1} & \multicolumn{1}{c}{$2 \sim 4$} & \multicolumn{1}{c}{5} & \multicolumn{2}{c}{6} & 7 \\
\cline { 5 - 6 } Depth (m) & \multicolumn{1}{c}{ top-75 } & \multicolumn{1}{c}{$75-110$} & $140-230$ & $230-300$ & $300-325$ & $325-$ bottom \\
\hline $\mathrm{C} / \mathrm{N}$ & $8.6 \pm 2.6$ & $8.5 \pm 3.4$ & $5.1 \pm 2.4$ & $7.8 \pm 2.8$ & $5.7 \pm 2.0$ & $3.6 \pm 1.7$ \\
$\delta^{13} \mathrm{C}(\% o)$ & $-24.1 \pm 2.1$ & $-21.2 \pm 2.4$ & $-25.2 \pm 0.6$ & $-22.6 \pm 2.8$ & $-24.7 \pm 0.6$ & $-24.9 \pm 0.6$ \\
$\delta^{15} \mathrm{~N}(\% \circ)$ & $5.4 \pm 3.6$ & $3.9 \pm 1.5$ & $3.7 \pm 1.0$ & $5.4 \pm 2.1$ & $4.5 \pm 0.8$ & $7.1 \pm 3.4$ \\
\hline
\end{tabular}

and then homogenized in an agate mortar. For the abundance analysis, a portion of the ground sample was wrapped in a tin capsule, and then combusted using a ThermoQuest EA1110 elemental analyzer to measure the total nitrogen and carbon content (TN and TC). Carbonate was removed from subsample by adding $2 \mathrm{~N}$ hydrochloric acid with occasionally agitation for 2 days. The samples then were neutralized by de-ionized water and dried at $60^{\circ} \mathrm{C}$ again. The same combustion process was also applied to measure total organic nitrogen and carbon content (TON and TOC). The results are equivalent to weight $\%$.

For stable isotope analyses $\left(\delta^{15} \mathrm{~N}\right.$ and $\left.\delta^{13} \mathrm{C}\right)$, the carbonate-free sample was combusted using an EA1110 CHNS analyzer connected via a Conflow to a Finnigan Delta Plus mass spectrometer. Results for isotope abundance are reported in per mil $(\%)$ relative to Pee Dee Belemnite (PDB) standard and relative to air $\mathrm{N}_{2}$, for $\delta^{13} \mathrm{C}$ and $\delta^{15} \mathrm{~N}$, respectively. The error for TOC and TON is $\pm 0.05 \mathrm{wt} \%$. The errors for carbon and nitrogen isotopic values are $\pm 0.1 \%$ and $\pm 0.2 \%$ o, respectively.

\section{RESULTS AND DISCUSSIONS}

Organic matter sources: applied by TOC, TON, C/N ratios and $\delta^{13} \mathrm{C}$

The TOC of the sediments varies from $0.07 \%$ to $1.45 \%$, with an average of $0.52 \%$ (Fig. 2). The TON has a similar downcore profile like TOC, with maxium $0.15 \%$ and minimum $0.01 \%$. Low organic carbon contents are observed in same sample probably related to the dilution effect caused by the high sedimentation rate and the poor preservation of the fresh organic matter, especially in coastal/fluvial environments in Taiwan (Oung et al., 2001). Neither TOC nor TON decreases downcore (Fig. 2 ); thus no evidence is found for selective loss of either $\mathrm{C}$ or $\mathrm{N}$ with time. Although some concentrations are close to the detecting limit, most point sets generally fall along a linear regression line pointing to origin with intercepts of 0.027 to $0.051 \mathrm{wt} \%$ with the least square fitting method (Table 2). Typical inorganic nitrogen excesses are usually reported on the basis of higher intercepts excess 0.05 wt\% (Emmer and Thunell, 2000). Therefore the results are indicating insignificant inorganic adsorption from
Table 2. Intercepts of TON and TOC correlation using the least square fitting method with $\pm 1 \sigma$

\begin{tabular}{lcc}
\hline & $\begin{array}{c}n \\
\text { total }=144\end{array}$ & $\begin{array}{c}\text { Intercept } \\
0.037 \pm 0.003\end{array}$ \\
\hline MIS 1 & 24 & $0.036 \pm 0.007$ \\
MIS 2 4 & 10 & $0.027 \pm 0.009$ \\
MIS 5 & 26 & $0.032 \pm 0.007$ \\
MIS 6 & 36 & $0.027 \pm 0.008$ \\
MIS 7 & 18 & $0.051 \pm 0.007$ \\
\hline
\end{tabular}

diagenesis interference. The only section in the study core that has intercept of $0.051 \pm 0.007$ is data-points of MIS 7 showing the relatively more possible adsorption of ammonium on clays.

$\mathrm{C} / \mathrm{N}$ ratios vary considerably between the lowest value of 1.3 at depth of $340.0 \mathrm{~m}$ and the highest of 15.0 at depth of $55.4 \mathrm{~m}$ (Fig. 2). The values are generally higher during MIS 2 (average $8.5 \pm 3.4$ ) and part of MIS 6 (average $7.8 \pm 2.8$ ), whereas they are lower in the rest of the cores (Table 1 ). $\delta^{13} \mathrm{C}$ values vary between -26.5 and $-17.0 \%$, showing higher $\delta^{13} \mathrm{C}$ values in the same intervals corresponding to high $\mathrm{C} / \mathrm{N}$ ratios. During MIS 1,5 , and 7 , the average values are close to $-25 \%$ as values derived from particulate organic matter in modern lagoonal or lacustrine sediments (Fontugne and Jonanneau, 1987; Wada et al., 1987).

Our results generally fall within the range of aquatic plankton with occasional high values in the range of a strong terrestrial input $(>10)$. Correspondence of high $\mathrm{C} /$ $\mathrm{N}$ ratios and high TOC has been postulated as a result of a coupling between higher fluxes of organic matter and improved preservation of its carbon content (Twichell et al., 2002). In subaqueous sediments the source-determined $\mathrm{C} / \mathrm{N}$ information is thought to be relatively conserved. As nitrogen is more labile than carbon, organic matter degradation usually results in an increase in $\mathrm{C} / \mathrm{N}$ ratio (Meyers, 1994, 1997). C/N ratios of MIS 7 are about 4 lower than in MIS 1, probably because of the adsorption of ammonium on clay from diagenesis and the increase of microbial mat in the deep core. Furthermore, this phenomenon has limited effect on the isotope com- 


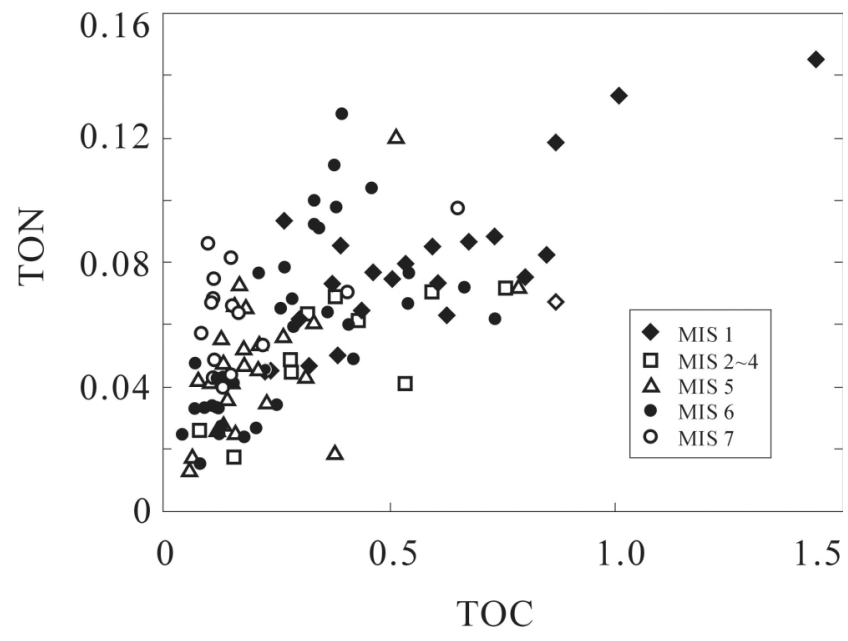

Fig. 3. Plot of TON vs. TOC. Data points are divided into five groups based on the depths and MIS.

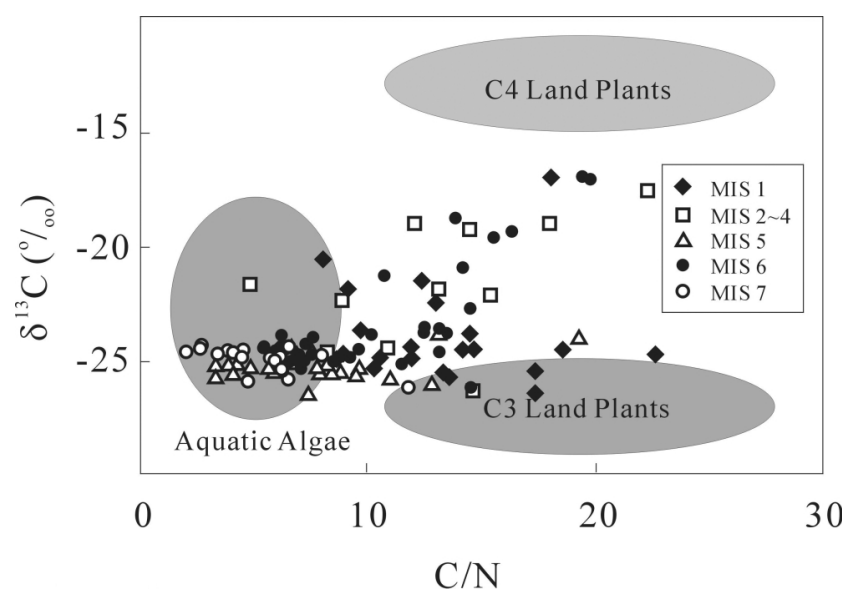

Fig. 4. Comparison of $\delta^{13} C$ and atomic $C / N$ values of sediment samples to elemental and isotopic indicators of bulk organic matter produced by aquatic algae, C3 and C4 land plants (adapted from Meyers, 1994).

position of the other part of the core, and the variations derived form different sources can still be well-preserved. The plot of $\mathrm{C} / \mathrm{N}$ vs. $\delta^{13} \mathrm{C}$ demonstrated that the organic matter source is mainly from a similar source of low $\mathrm{C} / \mathrm{N}$ and stable $\delta^{13} \mathrm{C}$ such as the autochthonous primary producers (Fig. 4). By the trend of terrestrial input toward high $\delta^{13} \mathrm{C}$ and $\mathrm{C} / \mathrm{N}$ (i.e. $\mathrm{C} 4$ end member), the terrestrial input of plant tissue that has high $\mathrm{C} / \mathrm{N}$ in this area is strong enough to show the main climate shift associated with a $\mathrm{C} 3-\mathrm{C} 4$ transition in vegetation.

\section{${ }^{15} \mathrm{~N}$ Enrichment in the Organic Sources}

The $\delta^{15} \mathrm{~N}$ values in the studied core fluctuate from 15.5 to $1.8 \%$ and 13.5 to $3.0 \%$ in MIS 1 and lower MIS 7 ,

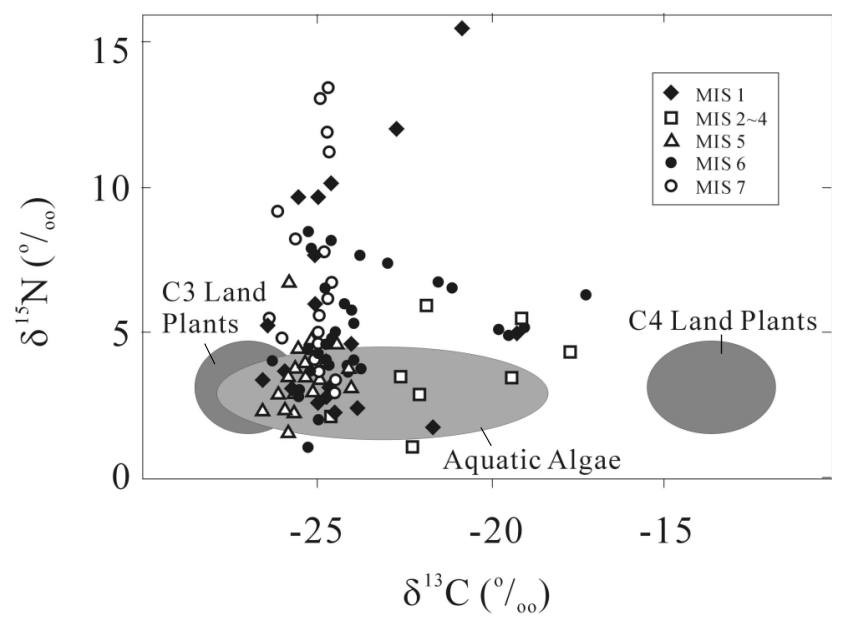

Fig. 5. Plot of $\delta^{15} N$ vs. C/N ratios showing comparison with the end members of marine algae, and land plants.

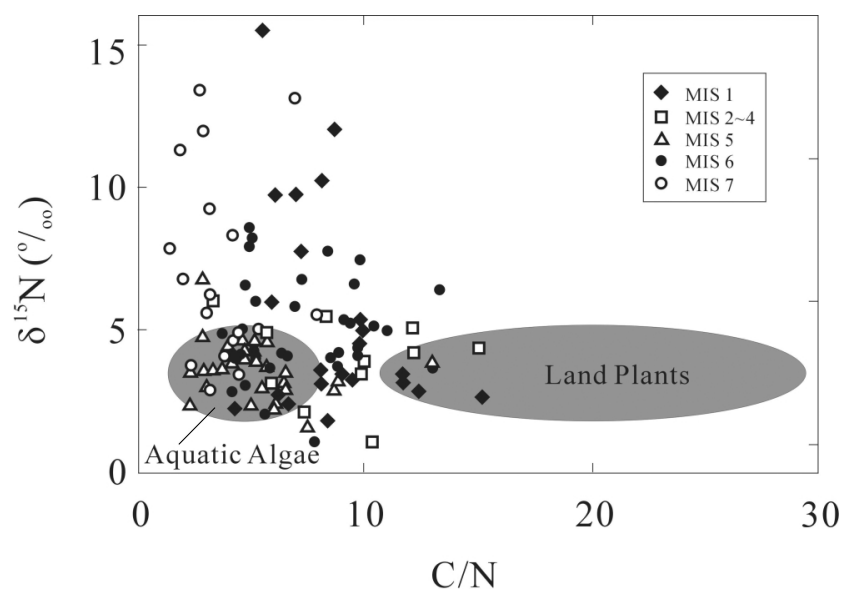

Fig. 6. Plot of $\delta^{15} N$ vs. $\delta^{13} C$ showing comparison with the end members of marine algae, C3 and C4 land plant.

respectively (Fig. 2). Comparing the $\delta^{15} \mathrm{~N}$ results with the sedimentary facies (Teng et al., 2001), reveals that while the basin was dominated by fluvial processes in MIS 26 , the $\delta^{15} \mathrm{~N}$ of organic matter was relatively low and steady (average 4.3\%o) (Fig. 2). Whereas in MIS 1 and 7, the $\delta^{13} \mathrm{C}$ and $\mathrm{C} / \mathrm{N}$ both show relatively small variation but the $\delta^{15} \mathrm{~N}$ varies considerably. Using plots of $\delta^{13} \mathrm{C}$ vs. $\delta^{15} \mathrm{~N}$ and $\mathrm{C} / \mathrm{N}$ vs. $\delta^{15} \mathrm{~N}$, an enriched ${ }^{15} \mathrm{~N}$ input in this core can be clearly detected (Figs. 5 and 6). This implies a different ${ }^{15} \mathrm{~N}$-enriched organic matter source in the above mentioned time periods. Based on an independent study on sedimentary facies, MIS 1 and 7 are identified as lacustrine or estuary, in which the possible reasons causing high $\delta^{15} \mathrm{~N}$ value are DIN (dissolved inorganic nitrogen) source change, early sedimentary diagenesis, and 
Table 3. Abundance and isotopic composition of plants collected from Tanshui modern estuary

\begin{tabular}{lccccc}
\hline & TOC $(\%)$ & TON $(\%)$ & $\mathrm{C} / \mathrm{N}$ & $\delta^{13} \mathrm{C}(\% o)$ & $\delta^{15} \mathrm{~N}(\% \circ)$ \\
\hline Ulva sp. (4)* & 34.41 & 1.04 & 34.9 & -24.9 & 8.7 \\
Ulva lactuca (3) & 33.58 & 2.14 & 15.7 & -25.3 & 7.1 \\
Entermorpha intestinalis (3) & 32.04 & 2.62 & 12.2 & -25.5 & 9.6 \\
Mangrove (4) & 54.93 & 3.93 & 14.0 & -25.6 & 11.3 \\
Reed (2) & 44.20 & 3.01 & 14.7 & -13.6 & 7.8 \\
Surface sediments (19) & 0.44 & 0.07 & 6.1 & -24.6 & 3.9 \\
\hline
\end{tabular}

*Bracketed number indicates the measured samples.

change of aquatic population.

In most sedimentary environments, the source of nitrogen for primary production is limited. Thus, primary producers tend to assimilate most DIN, giving $\delta^{15} \mathrm{~N}$ values of organic matters close to the source DIN (Horrigan et al., 1990; Altabet and Francois, 1994). If the origin of DIN has been enriched in ${ }^{15} \mathrm{~N}$ by certain processes, the final organic products will show high $\delta^{15} \mathrm{~N}$ values. Denitrification, for instance, occurred at suboxic or anoxic conditions, causes a large fractionation factor $\alpha \leqq$ 1.04 and makes the residual nitrate have much higher $\delta^{15} \mathrm{~N}$ values, e.g., +15 to $+30 \%$ o (Michener and Schell, 1994; Handley and Raven, 1992). Later utilization of the residual nitrate from denitrification of primary producers would result in heavier $\delta^{15} \mathrm{~N}$ values (Sigleo and Macko, 1985; Altabet et al., 1995; Ganeshram et al., 1995, 2000; Altabet et al., 1999; Emmer and Thunell, 2000).

Early diagenesis might also lead to high $\delta^{15} \mathrm{~N}$ values. Isotopic fractionation during decomposition is typically thought to result in heavy isotopic composition of the residual material (Altabet and Francois, 1994; Thornton and McManus, 1994; Ostrom et al., 1997; Sachs and Repeta, 1999). Figure 3 shows a relatively high proportion of TON in MIS 7, probably indicating that early diagenesis has affected this section. Besides, the corresponding TOC is low, suggesting that the aqueous environment was oxic and inappropriate for TOC preservation. As a consequence, high organic matter $\delta^{15} \mathrm{~N}$ was recorded in this section.

The last possible explanation is the change of aquatic population. In general, high $\delta^{15} \mathrm{~N}$ values may indicate high aquatic productivity. High $\delta^{15} \mathrm{~N}$ values and $\mathrm{C} / \mathrm{N}$ ratios in the sediments of estuarine cores have demonstrated an increase in autochthonous organic matter input such as macrophytes (Muller and Voss, 1999). At 9,000 years ago, seawater inundated and turned Taipei Basin into a shallow brackish bay, which might be habitatable for mangroves and macrophytes like the present-day estuary of the Tanshui River. The analyzed results of fresh materials of dominated aquatic population collected from the Tanshui estuary (Table 3) well support this hypothesis.
The macrophytes show relatively higher $\delta^{15} \mathrm{~N}$ values than other organic matter sources. The surface sediments have average $\delta^{15} \mathrm{~N}$ value of $3.9 \% \circ\left(\delta^{13} \mathrm{C}=-24.6 \%\right)$. The highest $\delta^{15} \mathrm{~N}$ value of $11.3 \%$ ( $\delta^{13} \mathrm{C}=-26.8 \%$ ) was measured from Entermorpha intestinalis, while the lowest value of $6.6 \% \circ\left(\delta^{13} \mathrm{C}=-24.2 \% o\right)$ is found for one sample of Ulva sp.

\section{Environmental change}

MIS 7 (bottom to depth of $325 \mathrm{~m}$ ) The relatively steady $\delta^{13} \mathrm{C}$ and $\mathrm{C} / \mathrm{N}$ represent a constant organic matter source from a mixture of autochthonous and terrestrial C3 plant material input that indicates a relatively warm period. Based on the above discussions of nitrogen isotope profile and the sedimentary environment facies, MIS 7 shows an oxic bottom-water condition that tends to give high $\delta^{15} \mathrm{~N}$ (average $7.1 \pm 3.4 \%$ ) (Table 1).

MIS 6 (depth of 325 230 m) At the beginning of MIS 6 at depth of 300-325 m, laminated and fine muddy layers indicate a deep anoxic lake. The averaged $\delta^{13} \mathrm{C}$ and $\mathrm{C} / \mathrm{N}$ ratio are $-24.7 \pm 0.6 \%$ and $5.7 \pm 2.0$, respectively. The $\delta^{15} \mathrm{~N}$ shifted from $7.1 \pm 3.4 \%$ in MIS 7 to an average of $4.5 \pm 0.8 \%$ out was relatively steady. This all implies that the source of organic matter was mainly from in situ primary producers with constant or almost no $\mathrm{C} 3$ terrestrial input. After the dammed lake period, the fluvial sediments restarted and recorded one of two significant arid periods in this core. $\delta^{13} \mathrm{C}$ values and $\mathrm{C} / \mathrm{N}$ ratio at that time shifted to $-22.6 \pm 2.8 \%$ and $7.8 \pm 2.8$ respectively, indicating that the terrestrial input increased, and $\mathrm{C} 4$ plants became an important source of organic matter. This could further imply that the climate was relatively arid, which is consistent with the pollen records. For instance, the chemical signal is consistent with palynological studies in continental shelves of eastern Asia which concluded a grass blooming event in MIS 6 due to the arid climate derived by weaker summer monsoon and stronger winter monsoon (Hope et al., 2004).

MIS 5 (depth of 230 140 m) MIS 6 ended at a thick layer of gravel. The study area reverted to a lacustrine and riverine environment in MIS 5. The $\delta^{13} \mathrm{C}$ values and $\mathrm{C} / \mathrm{N}$ 
ratios remained steady, implying that the environment was relatively stable and $\mathrm{C} 3$ plants became prevalent again. MIS 4 2 (depth 110 75 m) The sea level lowered again during MIS 4-2, leading to an environment with relatively strong erosion and less deposition. It resulted in only about 50 meters of deposition in MIS 4-2. Simultaneously rising $\mathrm{C} / \mathrm{N}$ ratios and $\delta^{13} \mathrm{C}$ values indicate increasing terrestrial $\mathrm{C} 4$ plant input, which was accordingly triggered by the arid climate.

MIS 1 (depth of 75 m top) In the early Holocene, the Basin was inundated by seawater and turned into a brackish lake. The climate became humid and mild, similar to the present-day. The $\delta^{13} \mathrm{C}$ values and $\mathrm{C} / \mathrm{N}$ ratios both vary in the beginning then remain steady later on, indicating that the environment became relatively stable, and C3 plants were dominant again. Our results of high $\delta^{15} \mathrm{~N}$ values and constant $\mathrm{C} / \mathrm{N}$ ratios in late MIS 1 possibly suggest that the mangroves and macrophytes were the main aquatic organic matter source in the estuary. This inference is also supported by the increasing TOC in this period.

\section{Conchusions}

The sedimentary organic $\delta^{13} \mathrm{C}, \delta^{15} \mathrm{~N}$ and $\mathrm{C} / \mathrm{N}$ ratios measured in the $\mathrm{Wu}-\mathrm{ku}$ core allow us to trace organic matter provenances of the paleo Taipei Basin. Early diagenesis due to the oxic-bottom water in the lower part of MIS 7 was recorded by increased $\delta^{15} \mathrm{~N}$ values of sedimentary organic matter. In the beginning of MIS 6 the $\mathrm{Wu}-\mathrm{ku}$ area became a deep, freshwater lake. The source of organic matter deposited was mainly in situ primary producers, which have steady $\delta^{13} \mathrm{C}$ values and $\mathrm{C} / \mathrm{N}$ ratios.

The major shift of $\delta^{13} \mathrm{C}$ values and $\mathrm{C} / \mathrm{N}$ ratios indicates that the terrestrial input increased in MIS 6, and C4 plant became an important source of organic matter. This implies that the climate was relatively cold and arid, which is consistent with the pollen records. MIS 6 terminated by a thick layer of gravel bed, and the Wu-ku area thereafter returned to a lacustrine and riverine environment in MIS 5. The $\delta^{13} \mathrm{C}$ values and $\mathrm{C} / \mathrm{N}$ ratios became relatively steady, implying that the environment was relatively stable. In the meantime, $\delta^{13} \mathrm{C}$ values reveal that $\mathrm{C} 3$ plants was dominant. Sea level was low during MIS 2-4 and only $\sim 50$ meters of sediment was deposited at Wu-ku. Coupled rising $\mathrm{C} / \mathrm{N}$ ratios and $\delta^{13} \mathrm{C}$ values are the indices of increasing terrestrial $\mathrm{C} 4$ plant material input in response to the arid climate. In early MIS 1, the Taipei Basin was inundated by seawater and turned into a brackish lake. The climate became humid and mild like the present. The mangroves and macrophytes were the main aquatic organic matter sources, and aquatic productivity increased at that time.
Acknowledgments-The authors would like to thank Dr. H. L. Hsieh, Dr. S. J. Kao and Dr. S. W. Lin for valuable discussion and advice. This study was supported by National Science Council under grant number of NSC89-2116-M-002-048 to Dr. Y. G. Chen.

\section{REFERENCES}

Altabet, M. A. and Francois, R. (1994) Sedimentary nitrogen isotopic ratio as a recorder for surface ocean nitrate utilization. Global Biogeochem. Cycles 8, 103-116.

Altabet, M. A., Francois, R., Murray, D. W. and Prell, W. L. (1995) Climate-related variations in denitrification in the Arabian Sea from sediment ${ }^{15} \mathrm{~N} /{ }^{14} \mathrm{~N}$ ratios. Nature 373, 506509.

Altabet, M. A., Pilskaln, C., Thunell, R., Pride, C., Sigman, D., Chavez, F. and Francois, R. (1999) The nitrogen isotope biogeochemistry of sinking particles from the margin of the Eastern North Pacific. Deep-Sea Res. I 46, 655-679.

Arthur, M. A., Dean, W. E. and Pratt, L. M. (1988) Geochemical and climatic effects of increased marine organic carbon burial at the Cenomanian/Turonian boundary. Nature 335, 714-717.

Bordovskiy, O. K. (1965) Accumulation and transformation of organic substances in marine sediments. Mar. Geol. 3, 3114.

Brandes, J. A. and Devol, A. H. (1997) Isotopic fractionation of oxygen and nitrogen in coastal marine sediments. Geochim. Cosmochim. Acta 61, 1793-1801.

Deines, P. (1980) The isotopic composition of reduced organic carbon. Handbook of Environmental Isotope Geochemistry 1, 329-406, Amsterdam-Oxford-New York.

Emmer, E. and Thunell, R. C. (2000) Nitrogen isotope fixation in Santa Barbara Basin sediments: Implications for denitrification in the eastern tropical North Pacific during the last 50,000 years. Paleoceanography 15, 377-387.

Fontugne, M. R. and Jonanneau, J. M. (1987) Modualtion of the particulate organic carbon flux to the ocean by a macrotidal estuary: evidence from measurements of carbon isotopes in organic matter from the Gironde system. Estuar. Coast. Shelf Sci. 24, 377-387.

Ganeshram, R. S., Pedersen, T. F., Calvert, S. E. and Murray, J. W. (1995) Large changes in oceanic nutrient inventories from glacial to interglacial periods. Nature 376, 755-758.

Ganeshram, R. S., Pedersen, T. F., Calvert, S. E., McNeill, G. W. and Fontugne, M. R. (2000) Glacial-interglacial variability in denitrification in the world's oceans: causes and consequences. Paleoceanography 15, 361-376.

Hakansson, S. (1985) A review of various factors influencing the stable carbon isotope ratio of organic lake sediments by the change from glacial to post-glacial environmental conditions. Quatern. Sci. Rev. 4, 135-146.

Handley, L. L., and Raven, J. H. (1992) The use of natural abundance of nitrogen isotopes in plant physiology and ecology: commissioned review. Plant Cell Env. 15, 965-985.

Hope, G., Kershaw, A. P., van der Kaars, S., Sun, X., Liew, P. M., Heusser, L. E., Takahara, H., McGlone, M., Miyoshi, N. and Moss, P. T. (2004) History of vegetation and habitat change in the Austral-Asia region. Quatern. Int. 118-119, 
$103-126$.

Horrigan, S. G., Montoya, J. P., Nevins, J. L. and McCarthy, J. J. (1990) Natural isotopic composition of dissolved inorganic nitrogen in Chesapeake Bay. Estuar. Coast. Shelf Sci. 30, 393-410.

Huang, C. Y. (1995) Study on the sediments of the Taipei Basin: Subsurface geology and engineering environments of Taipei Basin, Central Geological Survey, MOEA, Taipei, Taiwan, 1-53 (in Chinese).

Huon, S., Grousset, F. E., Burdloff, D., Bardoux, G. and Mariotti, A. (2002) Sources of fine-sized organic matter in North Atlantic Heinrich Layers: $\delta^{13} \mathrm{C}$ and $\delta^{15} \mathrm{~N}$ tracers. Geochim. Cosmochim. Acta 66, 223-239.

Liew, P. M., Huang, C. Y. and Tseng, M. H. (1997) Preliminary study on the late quaternary climatic environment of the Taipei Basin and its possible relation to basin sediments. $J$. Geol. Soc. China 40, 17-30.

Linsley, B. K. and Dunbar, R. B. (1994) The late Pleistocene history of surface water $\delta^{13} \mathrm{C}$ in the Sulu Sea: Possible relationship to Pacific deepwater $\delta^{13} \mathrm{C}$ changes. Paleaceanography 9, 317-340.

Liu, T. K., Wang, Y. and Chen, Y. G. (1988) C-14 dating of Sungshan Formation, Taipei Basin. 1988 Annual Meeting of Geological Society of China, 2 (in Chinese).

Macko, S. A. and Ostrom, N. E. (1994) Pollution studies using stable isotopes. Stable Isotopes in Ecology and Environmental Science 3 (Lajtha, K. and Michener, R. H., eds.), 45-62, Blackwell Scientific Publications.

Martinson, D. G., Pisias, N. G., Hays, J. O., Imbrie, J., Moore, T. C. and Shackleton, J. (1987) Age dating and the orbital theory of the Ice Ages: Development of a high-resolution 0 to 300,000-yr chronostratigraphy. Quatern. Res. 27, 1-29.

Meyers, P. A. (1994) Preservation of elemental and isotopic source identification of sedimentary organic matter. Chem. Geol. 114, 289-302.

Meyers, P. A. (1997) Organic geochemical proxies of palaeogeographic, paleolimnologic, and paleoclimatic processes. Org. Geochem. 27, 213-250.

Meyers, P. A. and Horie, S. (1993) An organic carbon isotopic record of glacial-postglacial change in atmospheric $\mathrm{pCO}_{2}$ in the sediments of Lake Biwa, Japan. Palaeogeogr. Palaeoclimatol. Palaeoecol. 105, 171-178.

Michener, R. H. and Schell, D. M. (1994) Stable isotope ratios as tracers in marine aquatic food web. Stable Isotopes in Ecology and Environmental Science 7 (Lajtha, K. and Michener, R. H., eds.), 138-157, Blackwell Scientific Publications.

Middelburg, J. J. and Nieuwenhuize, J. (1998) Carbon and nitrogen stable isotopes in suspended matter and sediments from the Shelde Estuary. Mar. Chem. 60, 217-225.

Minagawa, M. and Wada, E. (1984) Stepwise enrichment of ${ }^{15} \mathrm{~N}$ along food chains: further evidence, the relation between ${ }^{15} \mathrm{~N}$ and animal age. Geochim. Cosmochim. Acta 48 , $1135-1140$.

Muller, A. and Voss, M. (1999) The paleoenvironments of coastal lagoons in the southern Baltic Sea, II. $\delta^{13} \mathrm{C}$ and $\delta^{15} \mathrm{~N}$ ratios of organic matter-sources and sediments. Palaeogeogr. Palaeoclimatol. Palaeoecol. 145, 17-32.

Muzuka, A. N. N. and Hillaire-Marcel, C. (1999) Burial rates of organic matter along the eastern Canadian Margin and stable isotope constraints on its origin and diagenetic evolution. Mar. Geol. 160, 251-270.

Ohkouchi, N., Kawamura, H. and Taira, A. (1997) Fluctuation of terrestrial and marine biomakers in the western tropical Pacific during the last 23,000 years. Paleoceanography 12, 623-630.

O'Leary, M. H. (1988) Carbon isotopes in photosynthesis. BioSciences 38, 328-336.

Ostrom, N. E., Macko, S. A., Deibel, D. and Thompson, R. J. (1997) Seasonal variation in the stable carbon and nitrogen isotope biogeochemistry of a coastal cold ocean environment. Geochim. Cosmochim. Acta 61, 2929-2942.

Oung, J. N., Lin, Y. D., Lin, S. Y., Sung, Q. C., Liu, T. K. and Yang, C. H. (2001) Organic Geochemistry of Sediments in the Southwestern Coastal Plain, Taiwan. West. Pac. Earth Sci. 1(3), 373-390.

Owens, N. J. P. (1987) Natural variations in ${ }^{15} \mathrm{~N}$ in the marine environment. Advances in Marine Biology 24, 389-451, Academic Press.

Prahl, F. G., Bennett, J. T. and Carpenter, R. (1980) The early diagenesis of aliphatic hydrocarbons and organic matter in sedimentary particulates from Dabob Bay, Washington. Geochim. Cosmochim. Acta 44, 1967-1976.

Sachs, J. P. and Repeta, D. J. (1999) Oligotrophy and nitrogen fixation during eastern Meditereanean sapropel events. Science 286, 2485-2488.

Schoeninger, M. J. and DeNiro, M. J. (1984) Nitrogen and carbon isotopic composition of bone collagen from marine and terrestrial animals. Geochim. Cosmochim. Acta 48, 625-639.

Schubert, C. J. and Calvert, S. E. (2001) Nitrogen and Carbon isotopic composition of marine and terrestrial organic matter in Arctic Ocean sediments: implications for nutrient utilization and organic matter composition. Deep-Sea Res. I 48, 789-810.

Shackleton, N. J., Imbrie, J. and Hall, M. A. (1983) Oxygen and carbon isotope record of East Pacific core V19-30: implications for the formation of deep water in the Late Pleistocene North Atlantic. Earth Planet. Sci. Lett. 65, 233244.

Sigleo, A. C. and Macko, S. A. (1985) Stable isotope and amino acid composition of estuarine dissolved colloidal material. Marine and Estuarine Geochemistry, 29-46, Lewis Publishers.

Street-Perrott, F. A., Huang, Y., Perrott, R. A., Eglington, N. G., Barker, P., Khelifa, L. B., Harkness, D. D. and Olago, D. O. (1997) Impact of lower atmospheric carbon dioxide on tropical mountain ecosystems. Science 278, 1422-1426.

Stuiver, M. (1975) Climate versus changes in ${ }^{13} \mathrm{C}$ content of the organic component of lake sediments during the Late Quaternary. Quatern. Res. 5, 251-262.

Talbot, M. R. and Johannessen, T. (1992) A high resolution palaeoclimatic record for the last 27,500 years in tropical West Africa from the carbon and nitrogen isotopic composition of lacustrine organic matter. Earth Planet. Sci. Lett. 10, 23-37.

Teng, L. S., Yuan, P. B., Yu, N. T. and Peng, C. H. (2000) Sequence stratigraphy of the Taipei Basin deposits: A preliminary study. J. Geol. Soc. China 43, 497-520. 
Teng, L. S., Lee, C. T., Peng, C., Chen, W. and Chu, C. (2001) Origin and geological evolution of the Taipei Basin, northern Taiwan. West. Pac. Earth Sci. 1(2), 115-142.

Tenzer, G. E., Meyers, P. A., Robbins, J. A., Eadie, B. J., Morehead, N. R. and Lansing, M. B. (1999) Sedimentary organic matter record of recent environmental changes in the St. Marys River ecosystem, Michigan-Ontario border. Org. Geochem. 30, 133-146.

Thornton, S. F. and McManus, J. (1994) Application of organic carbon and nitrogen stable isotope and $\mathrm{C} / \mathrm{N}$ ratios as source indicators of organic matter provenance in estuarine systems: evidence from the Tay Estuary, Scotland. Estuar. Coast. Shelf Sci. 38, 219-233.

Twichell, S. C., Meyers, P. A. and Diester-Haass, L. (2002) Significance of high $\mathrm{C} / \mathrm{N}$ ratios in organic-carbon-rich Neogene sediments under the Benguela Current Upwelling System. Org. Geochem. 33, 715-722.

Tyson, R. V. (1995) Abundance of organic matter in sediments: TOC, hydrodynamic equivalence, dilution and flux effects. Sedimentary Organic Matter: Organic Facies and Palynofacies, 81-118, Chapman \& Hall.

Voss, M. and Struck, U. (1997) Stable nitrogen and carbon isotopes as indicators of eutrophication of the Oder River (Baltic Sea). Mar. Chem. 59, 35-49.

Wada, E., Kadonaga, T. and Matuse, S. (1975) ${ }^{15} \mathrm{~N}$ abundance in nitrogen of naturally occurring substances and global assessment of denitrification from isotopic viewpoint. Geochem. J. 9, 139-148.

Wada, E., Terazaki, M., Kabaya, Y. and Nemoto, T. (1987) ${ }^{15} \mathrm{~N}$ and ${ }^{13} \mathrm{C}$ abundances in Antartic Ocean with Emphasis on the biogeochemical structure of the food web. Deep-Sea Res. 34, 829-841.

Wang, C. Y., Hsiao, W. C. and Sun, C. T. (1994) Reflection seismic stratigraphy in the Taipei Basin (I) - northern Taipei Basin. J. Geol. Soc. China 37(1), 69-95.

Wang, C. Y., Hsiao, W. C. and Sun, C. T. (1995) Reflection seismic stratigraphy in the Taipei Basin (II) - western and southern Taipei Basin. J. Geol. Soc. China 38(2), 141-172.

Wang-Lee, C. M., Cheng, Y. M. and Wang, Y. (1978) Geological and sedimentary study. Taiwan Mineral Industry 30(4), 78-108.

Water Resources Bureau, Ministry of Economic Affairs (1995) Hydrological Year Book of Taiwan, Republic of China: Table 2-1 Hydrological Characteristic Rivers in Taiwan (in Chinese).

Wei, K., Chen, Y. G. and Liu, T. K. (1998) Sedimentary history of the Taipei Basin with constraints from thermoluminescence dates. J. Geol. Soc. China 41(1), 105125 . 